\title{
Cloning and Characterization of a Novel Chromosomal Drug Efflux Gene in Staphylococcus aureus
}

\author{
Koji NaruI, ${ }^{a}$ Norihisa Noguchi,,${ }^{* a}$ Kazunori WaKasugi, ${ }^{b}$ and Masanori Sasatsu ${ }^{a}$ \\ ${ }^{a}$ Department of Microbiology, School of Pharmacy, Tokyo University of Pharmacy and Life Science; 1432-1 Horinouchi, \\ Hachioji, Tokyo 192-0392, Japan: and ${ }^{b}$ Division of Clinical Immunohaematology, Department of Internal Medicine, \\ Tokyo Medical University at Hachioji Medical Center; 1163 Tatemachi, Hachioji, Tokyo 193-0998, Japan. \\ Received August 2, 2002; accepted October 2, 2002
}

\begin{abstract}
A novel drug efflux gene (named $\operatorname{sep} A$, staphylococcal efflux pump gene) is cloned from antiseptic-resistant mutants of Staphylococcus aureus into Escherichia coli. The sepA gene conferred the reduction of susceptibility to acriflavine and the acceleration of ethidium bromide efflux from the $E$. coli cells. The $\operatorname{sep} A(474 \mathrm{bp})$ encoded the protein that has four predicted transmembrane segments. These results indicate that sep $A$ gene is a multidrugresistant gene and encodes a drug efflux protein.
\end{abstract}

Key words Staphylococcus aureus; antiseptic resistance; efflux protein; transmembrane

In Staphylococcus aureus, the qacA gene group (including $q a c B$ ) and the $s m r$ gene group (including $q a c C, q a c D$ and $e b r$ ) of plasmids and norA gene of the chromosome confer resistance to antiseptics and disinfectants. ${ }^{1-4)}$ The QacA and NorA classes are considered as members of a major facilitator superfamily (MFS family) and each consists of a predicted structure that has 14 and 12 transmembrane segments (TMS), respectively. ${ }^{2,5}$ On the other hand, the smr gene encodes a small protein that comprises 4 TMS and belongs to the small multidrug resistance (SMR) family. ${ }^{2,3)}$ These proteins export drugs in a process dependent on the proton motive force. ${ }^{2,5,6}$ Dyes, such as ethidium bromide and acridine, and surfactants, such as benzalkonium and benzethonium, are recognized by QacA and Smr. Furthermore, NorA also recognizes antiseptics as well as fluoroquinolones. ${ }^{1-4)}$

We previously examined the correlation between sensitivity to antiseptics and the presence of qacA and $s m r$ genes in methicillin-resistant $S$. aureus (MRSA). ${ }^{7}$ Low-level antiseptic-resistant strains were found, which neither had qacA, smr nor mutations of norA gene, but were widely spread in Japan. Furthermore, low-level antiseptic-resistant mutants of $S$. aureus could be frequently isolated with selection by antiseptics. ${ }^{8)}$ These results suggested that some other multidrug-resistant gene(s) were located on the chromosome of S. aureus. In this report, which is an extension to the above report, ${ }^{8)}$ a novel chromosomal drug efflux gene of $S$. aureus was cloned and characterized.

\section{MATERIALS AND METHODS}

Bacterial Strains, Plasmids and Primers Bacterial strains and plasmids used are listed Table 1. S. aureus RN2677 mutants, TP186 and TP187, which were obtained from benzalkonium chloride (BKC) and chlorhexidine gluconate (CHG) selection had no mutation in the norA gene. ${ }^{8)}$ Primers, norA $+2 \mathrm{a}$ (nucleotide positions, 541 to 560 ) and norA-6 (979 to 960), were designed from the sequence of norA gene by Yoshida et al. ${ }^{4)}$

Manipulation of DNA Manipulation of DNA and transformation into Escherichia coli were accomplished by the methods outlined by Sambrook et al. ${ }^{9)}$ Transformations of Bacillus subtilis and S. aureus were performed using compe- tent cells, as described previously. ${ }^{10)}$ Deletion derivatives were constructed by the polymerase chain reaction (PCR) method. $^{10)}$

Susceptibility to Antiseptics The susceptibility of transformants to antiseptics was determined by measurement of the minimum inhibitory concentration (MIC) using the agardilution method, as outlined by NCCLS. ${ }^{12)}$ The dose for $50 \%$ growth inhibition $(50 \%$ growth inhibitory concentration, $\mathrm{IC}_{50}$ ) was determined as described previously. ${ }^{13)}$ Measurement of susceptibility using a gradient plate was performed as described by Finan et al. ${ }^{14)}$

Efflux of Ethidium Bromide Bacteria were first exposed to EB $(2 \mu \mathrm{g} / \mathrm{ml})$ in the presence of carbonyl cyanide $m$-chlorophenyl hydrazone (CCCP, $8.2 \mu \mathrm{g} / \mathrm{ml}$ ) for $20 \mathrm{~min}$ at $37^{\circ} \mathrm{C}$. The cells were then pelleted by centrifugation and resuspended in fresh uptake buffer. The efflux of EB from the cells was measured as a decrease in fluorescence intensity. ${ }^{\text {) }}$

Table 1. The Bacterial Strains and Plasmids

\begin{tabular}{|c|c|c|}
\hline Strain or plasmid & Description (resistance marker) & Reference \\
\hline \multicolumn{3}{|l|}{ Strain: } \\
\hline \multicolumn{3}{|l|}{ S. aureus } \\
\hline RN2677 & $\mathrm{r}-, \mathrm{NOV}^{\mathrm{r}}, \mathrm{RIF}^{\mathrm{r}}$ & 7) \\
\hline TP186 & RN2677 mutant obtained from BKC selection & 8) \\
\hline TP187 & RN2677 mutant obtained from CHG selection & 8) \\
\hline E. coli $\mathrm{DH} 5 \alpha$ & & 9) \\
\hline \multicolumn{3}{|l|}{ B. subtilis } \\
\hline BR151 & $\operatorname{trpC2}$, lys-3, metB10 & 10) \\
\hline \multicolumn{3}{|l|}{ Plasmid: } \\
\hline pSTV28 & plasmid vector in $E$. coli $\left(\mathrm{CP}^{\mathrm{r}}\right)$ & 11) \\
\hline pUC18 & plasmid vector in $E$. coli ( $\left.\mathrm{AP}^{\mathrm{r}}\right)$ & 9) \\
\hline pUB110 & plasmid vector in B. subtilis and $S$. aureus $\left(\mathrm{NEO}^{\mathrm{r}}\right)$ & 10) \\
\hline pTZ2600 & 4-kb Sau3AI fragment of TP186 in pSTV28 (CPr) & This study \\
\hline pTZ2610 & 7-kb Sau3AI fragment of TP187 in pSTV28 (CPr) & This study \\
\hline pTZ2620 & 10-kb Sau3AI fragment of TP187 in pSTV28 (CP $)$ & This study \\
\hline pTZ2601 & 4-kb XbaI-EcoRI fragment of pTZ2600 in pUC18 (AP') & ) This study \\
\hline pTZ2601 $\Delta 1$ & 2.7-kb PCR product of pTZ2601 in pUC18 (APr) & This study \\
\hline pTZ2601 $\Delta 2$ & 2-kb PCR product of pTZ2601 in pUC18 (AP') & This study \\
\hline pTZ2601 $\Delta 3$ & 1-kb PCR product of pTZ2601 in pUC18 $\left(\mathrm{AP}^{\mathrm{r}}\right)$ & This study \\
\hline pTZ2602 & $\begin{array}{l}\text { 4-kb SphI-EcoRI fragment of pTZ2601 in pUB110 } \\
\left(\mathrm{NEO}^{\mathrm{r}}\right)\end{array}$ & This study \\
\hline
\end{tabular}

NOV, novobiocin; RIF, rifampicin; BKC, benzalkonium chloride; CHG, chlorhexidine gluconate; CP, chloramphenicol; AP, ampicillin; NEO, neomycin; ${ }^{\mathrm{r}}$, resistance; r-, restriction-defective mutant. 
Nucleotide Sequence Accession Number The nucleotide sequence has been deposited in the DDBJ, EMBL and GenBank databases under accession number AB078343.

\section{RESULTS}

Cloning and Susceptibility Chromosomal DNA of mutants TP186 and TP187 (those were obtained by selection of antiseptics) were digested partially with endonuclease Sau3AI, and the fragments were inserted into the BamHI site of chloramphenicol (CP)-resistance plasmid pSTV28 and transferred into $E$. coli DH5 $\alpha$. Resistance strains to acriflavine (AF) and $\mathrm{CP}$ in these transformants were found in 8 and 19 strains out of approximately 1400 strains from TP186 and TP187, respectively. The presence of nor $A$ gene was tested in these 27 transformants resistant by PCR amplification using the primers norA $+2 \mathrm{a}$ and norA-6. Three strains in which the $439 \mathrm{bp}$ nor $A$ fragment was not amplified were obtained. pTZ2600 carried a 4-kb chromosomal fragment of TP186 while pTZ2610 and pTZ2620 carried 7-kb and 10-kb chromosomal fragment of TP187, respectively. pTZ2601 was constructed by the insertion of 4-kb $X b a \mathrm{I}-E c o$ RI fragment of pTZ2600 into pUC18. MICs were determined for the strains carrying three plasmids (Table 2). The MIC of AF, BKC ang CHG for E. coli carrying pTZ2601 was elevated. Resistance to EB was not demonstrated by determination of MICs, but the strains carrying pTZ2600, pTZ2610, pTZ2620 or pTZ2601 could grow on the medium by the area containing a higher concentration on EB gradient plate (data not shown). The $\mathrm{IC}_{50}$ of AF for E. coli carrying pTZ2601 and pUC18 was 11.8 and $6.5 \mu \mathrm{g} / \mathrm{ml}$. The results indicated that pTZ2601 had a resistance gene on chromosome of $S$. aureus.

Efflux of Ethidium Bromide To study the resistance mechanism, efflux was measured using the fluorescent substance EB (Fig. 1). Setting the EB efflux rate of E. coli carrying pUC18 as 1 , the EB efflux rate of $E$. coli carrying pTZ2601 was $3.05 \pm 0.26$. This result indicated that the gene product pumped out the drug EB from the cells to the medium.

Characterization of $\operatorname{sep} A$ Gene The nucleotide sequence of the insert of the recombinant plasmid was determined (accession number AB078343). The insert of pTZ2601 was $4064 \mathrm{bp}$ and had five open reading frames (ORF). The 5'-terminal region of ORF1 and 3 '-terminal region of ORF5 were missing. Plasmids pTZ2610 and pTZ2620 had ORF2, ORF3 and ORF4 that were also carried by pTZ2601. To determine the location of the antiseptic resistance gene, various deletion derivatives, pTZ2601 $\Delta 1$, pTZ2601 $\Delta 2$ and pTZ2601 $\Delta 3$, were constructed and $\mathrm{IC}_{50}$ of $\mathrm{AF}$ for deletion derivatives were measured (Fig. 2). The $\mathrm{IC}_{50}$ of AF for deletion derivatives that had intact ORF4 was high, indicating that ORF4 corresponded to the antiseptic resistance gene. ORF4 was named antiseptic resistance gene, $\operatorname{sep} A$ (staphylococcal efflux pump gene). The $\operatorname{sep} A$ gene consisted of $474 \mathrm{bp}$ and theoretically encoded a protein of 157 amino acids with a molecular weight of approximately 18900.

Expression of $\operatorname{sep} \boldsymbol{A}$ Gene in $\boldsymbol{S}$. aureus To examine the expression of $\operatorname{sep} A$ gene in $S$. aureus, we constructed recombinant plasmid pTZ2602 by insertion of the EcoRI-SphI fragment of pTZ2601 into EcoRI-SphI site of pUB110 in B. sub-
Table 2. MICs of Antiseptics for S. aureus and E. coli

\begin{tabular}{|c|c|c|c|c|c|c|c|}
\hline \multirow{2}{*}{ Strain } & & \multirow{2}{*}{ Plasmid } & \multicolumn{5}{|c|}{$\mathrm{MIC}(\mu \mathrm{g} / \mathrm{ml})$} \\
\hline & & & $\mathrm{AF}^{a)}$ & $\mathrm{EB}^{a)}$ & $\left.\mathrm{BKC}^{a}\right)$ & $\mathrm{ADH}^{a)}$ & $\mathrm{CHG}^{a)}$ \\
\hline \multirow[t]{5}{*}{ S. aureus } & RN2677 & none & 4 & 2 & 1 & 16 & 2 \\
\hline & & pUB110 & 4 & 2 & 1 & 16 & 2 \\
\hline & & pTZ2602 & 8 & 2 & 2 & 16 & 4 \\
\hline & $\mathrm{TP} 186^{b)}$ & none & 16 & 4 & 2 & 16 & 4 \\
\hline & $\mathrm{TP} 187^{b)}$ & none & 64 & 16 & 4 & 16 & 4 \\
\hline \multirow[t]{7}{*}{ E. coli } & DH5 $\alpha$ & none & 16 & 64 & 16 & 64 & 1 \\
\hline & & pSTV28 & 16 & 64 & 16 & 64 & 1 \\
\hline & & pTZ2600 & 32 & 64 & 32 & 64 & 2 \\
\hline & & pTZ2610 & 32 & 64 & 32 & 64 & 2 \\
\hline & & pTZ2620 & 32 & 64 & 32 & 64 & 2 \\
\hline & & pUC18 & 16 & 64 & 16 & 64 & 1 \\
\hline & & pTZ2601 & 32 & 64 & 32 & 64 & 2 \\
\hline
\end{tabular}

a) $\mathrm{AF}$, acriflavine; $\mathrm{EB}$, ethidium bromide; $\mathrm{BKC}$, benzalkonium chloride; $\mathrm{ADH}$, alkyldiaminoethylglycine hydrochloride; $\mathrm{CHG}$, chlorhexidine gluconate. b) RN2677 mutant.

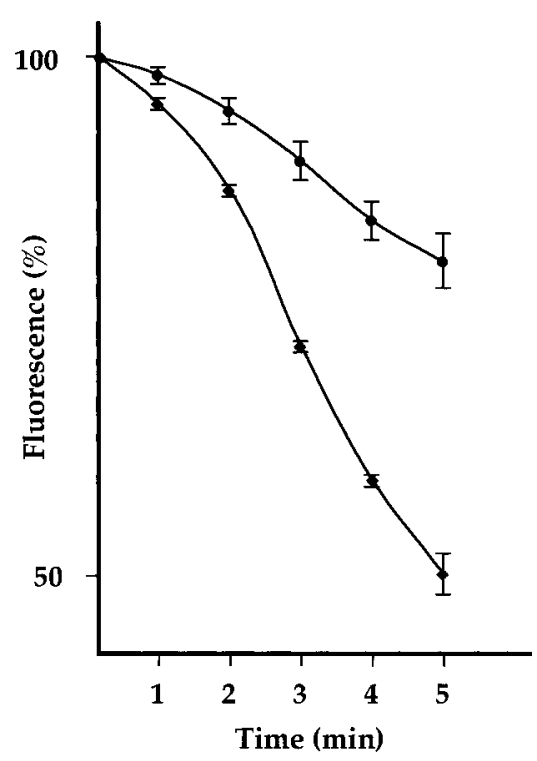

Fig. 1. Efflux of Ethidium Bromide in E. coli DH5 $\alpha$ Carrying Plasmid The fluorescence intensity was measured after removal of CCCP. Symbols: pUC18; $\diamond$, pTZ2601. Data represent the mean \pm S.D. of four experiments.

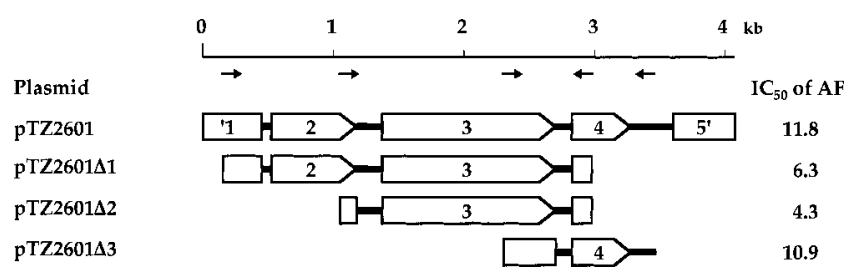

Fig. 2. Properties and Resistance of E. coli DH5 $\alpha$ Carrying Deletion Derivatives of pTZ2601

Small arrows indicate the position and direction of primers used in this study. ORFs are indicated by arrows and boxes. Arrows represent encodable ORF. $\mathrm{IC}_{50}, 50 \%$ growth inhibitory concentration $(\mu \mathrm{g} / \mathrm{ml})$; $\mathrm{AF}$, acriflavine.

tilis. The pTZ2602 was introduced into the parental $S$. aureus $\mathrm{RN} 2677$. The MICs of AF, BKC and CHG for S. aureus carrying pTZ2602 were elevated (Table 2). On AF gradient plate, the strain with pTZ2602 plasmid could grow on the medium by the area containing a higher concentration of AF (Fig. 3), indicating that the $\operatorname{sep} A$ gene could express low- 
level resistance to antiseptics in $S$. aureus.

\section{DISCUSSION}

In this study, a novel chromosomal $\operatorname{sep} A$ gene that conferred low-level resistance to antiseptics and dyes was cloned in $E$. coli and $S$. aureus. The amino acid sequence of SepA exhibited no significant homology to those of published genes for drug-resistance and drug-efflux pump. The hydrophobicity analysis ${ }^{15)}$ of SepA suggested that SepA contained approximately 4 transmembrane segments similar to proteins of SMR family. The SMR family has three conserved motifs, ${ }^{2}$ but these conserved motifs were not recognized in SepA, suggesting that SepA belonged to a new family different from SMR family. Previous studies indicated that Glu-13, Glu-24, Trp-62 and Glu-80 in 107 amino acid residues of Smr were involved in the drug/proton antiport and determining the specificity of drug resistance. ${ }^{6)}$ Glu-13 and Trp-62 were located in 1st and 3rd transmembrane segments, respectively, and Glu-24 and Glu-80 were located in the hydrophilic polypeptide chain between 1 st and 2 nd and between 3rd and 4th transmembrane segments in Smr, respectively (Fig. 4). Four of these important amino acid residues of Smr (Glu-13, Glu-24, Trp-62 and Glu-80) were also found in SepA (Glu-81, Glu-93, Trp-130 and Glu-149). The patterns of distribution important amino acid residues in the polypeptide chain of SepA were similar to those of Smr, but with one difference the SepA residues were encompassed with putative transmembrane segments 2-4, while in the $\mathrm{Smr}$ they were encompassed with transmembrane segments $1-3$.

The sep $A$ gene sequence was $99.2 \%$ (470/474 bp) identical to the SA1971 gene on the newly released genome $S$. aureus

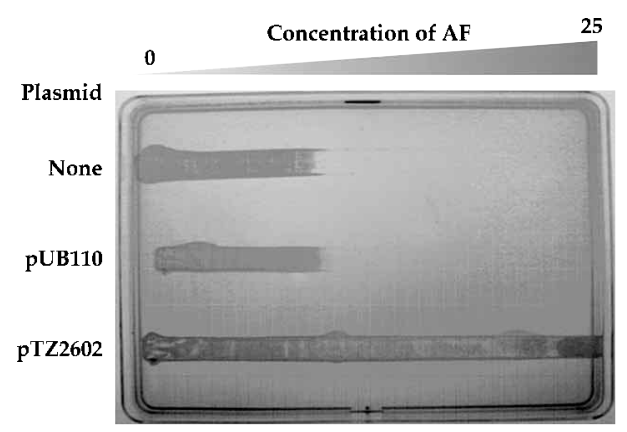

Fig. 3. Growth of S. aureus RN2677 Carrying Various Plasmids on a Gradient Plate

The minimum and maximum acriflavine concentrations $(\mu \mathrm{g} / \mathrm{ml})$ on the gradient plate are shown.
N315. ${ }^{16)}$ The amino acid sequence of SepA was the same as the SA1971 gene product (Protein ID: BAB43260.1). Therefore, our study showed that the SA1971 gene (sepA gene) is related to multidrug-resistance and encodes a drug efflux protein.

The nucleotide sequence of $\operatorname{sep} A$ gene of susceptible strain RN2677 was also determined and compared to the $\operatorname{sep} A$ gene of TP186 and TP187. No mutations were identified in the sepA gene of TP186 and TP187, suggesting that other genes related to multidrug-resistance resided in the chromosome of $S$. aureus. However, in this study, we demonstrated that the increase in the copy number of $\operatorname{sep} A$ gene by cloning into plasmids contributed to the elevated resistance, similar to the nor $A$ gene. ${ }^{17)}$ Therefore, it is possible that mutations that lead to overexpression of $\operatorname{sep} A$ gene may cause low-level resistance to antiseptics in $S$. aureus.

Acknowledgements The authors thank Y. Suga and I. Kamiya for the expert technical assistance. This work was supported by grants for private universities provided by the Ministry of Education, Culture, Sports, Science and Technology and by the Promotion and Mutual Aid Corporation for Private School of Japan.

\section{REFERENCES}

1) Rouch D. A., Cram D. S., DiBerardino D., Littlejohn T. G., Skurray R. A., Mol. Microbiol., 4, 2051-2062 (1990).

2) Putman M., van Veen H. W., Konings W. N., Microbiol. Mol. Biol. Rev., 64, 672-693 (2000).

3) Grinius L., Dreguniene G., Goldberg E. B., Liao C. H., Projan S. J., Plasmid, 27, 119-129 (1992).

4) Yoshida H., Bogaki M., Nakamura S., Ubukata K., Konno M., J. Bacteriol., 172, 6942-6949 (1990).

5) Paulsen I. T., Skurray R. A., Gene, 124, 1-11 (1993).

6) Grinius L. L., Goldberg E. B., J. Biol. Chem., 269, 29998-30004 (1994).

7) Noguchi N., Hase M., Kitta M., Sasatsu M., Deguchi K., Kono M., FEMS Microbiol. Lett., 172, 247-253 (1999).

8) Noguchi N., Tamura M., Narui K., Wakasugi K., Sasatsu M., Biol. Pharm. Bull., 25, 1129-1132 (2002).

9) Sambrook J., Fritsch E. F., Maniatis T., "Molecular Cloning: A Laboratory Manual," 2nd Edition. Cold Spring Harbor Laboratory Press, Cold Spring Harbor, N.Y., 1989.

10) Noguchi N., Tamura Y., Katayama J., Narui K., FEMS Microbiol. Lett., 172, 247-253 (1998).

11) Noguchi N., Takada K., Katayama J., Emura A., Sasatsu M., J. Bacteriol., 182, 5052-5058 (2000).

12) National Committee for Clinical Laboratory Standards. Methods for dilution antimicrobial susceptibility tests for bacteria that grow aerobically-fourth edition; approved standard M7-A4. National Committee for Clinical Laboratory Standards, Wayne, Pa., 1997.

13) Noguchi N., Emura A., Sasatsu M., Kono M., Biol. Pharm. Bull., 17, $352-355$ (1994).

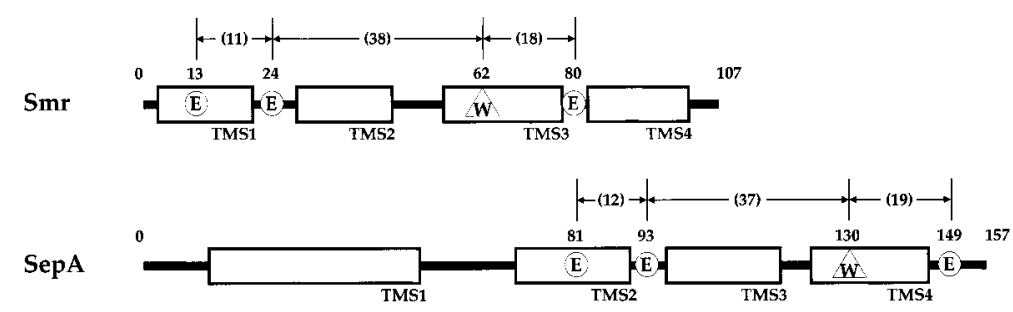

Fig. 4. Putative Transmembrane Segments of Smr and SepA

Boxes and lines are transmembrane segments (TMS) and hydrophilic domain. Important amino acid residues, reported by Grinius and Goldberg, ${ }^{\text {() }}$ are shown by circles and triangles. Intervals of important amino acid residues are shown in parentheses. 
14) Finan J. E., Archer G. L., Pucci M. J., Climo M. W., Antimicrob. Agents Chemother, 45, 3070-3075 (2001).

15) Kyte J., Doolittle R. F., J. Mol. Biol., 157, 105-132 (1982).

16) Kuroda M., Ohta T., Uchiyama I., Baba T., Yuzawa H., Kobayashi I., Cui L., Oguchi A., Aoki K., Nagai Y., Lian J., Ito T., Kanamori M., Matsumaru H., Maruyama A., Murakami H., Hosoyama A., MizutaniUi Y., Takahashi N. K., Sawano T., Inoue R., Kaito C., Sekimizu K.,
Hirakawa H., Kuhara S., Goto S., Yabuzaki J., Kanehisa M., Yamashita A., Oshima K., Furuya K., Yoshino C., Shiba T., Hattori M., Ogasawara N., Hayashi H., Hiramatsu K., Lancet, 357, 1225-1240 (2001).

17) Sun L., Sreedharan S., Plummer K., Fisher L. M., Antimicrob. Agents Chemother, 40, 1665-1669 (1996). 